\title{
Changes in State Unemployment Insurance Rules during the COVID-19 Outbreak in the U.S.
}

\section{Zoe Xie}

Federal Reserve Bank of Atlanta

\section{Summary:}

The COVID-19 pandemic led to an unprecedented expansion in unemployment insurance (UI) eligibility across states. While more than forty states had modified UI rules by the end of March, not all states responded in the same way. In this article, I summarize the changes to state UI rules in response to the crisis and explore factors that have contributed to the variation in states' responses.

\section{Key findings:}

1. States differ in whether and how they extend UI eligibility to workers who are unable to work due to quarantine, COVID-19 related illness, caring for sick family or at-home children.

2. The service sector share of employment in a state is positively correlated with extended UI eligibility coverage.

3. The number of confirmed COVID-19 cases is only weakly correlated with UI eligibility expansion, while the solvency of a state's UI fund does not limit the expansions.

\section{CENTER FOR QUANTITATIVE ECONOMIC RESEARCH}

\section{CENTER FOR HUMAN CAPITAL STUDIES}

CENTER FOR FINANCIAL INNOVATION AND STABILITY

\section{CENTER FOR HOUSING} AND POLICY 
No. 02-2020 • April 2020

\section{Changes inState Unemployment Insurance Rules duringthe COVID-19 Outbreak intheU.S.}

Summary: The COVID-19 pandemic led to an unprecedented expansion in unemployment insurance (UI) eligibility across states. While more than forty states had modified UI rules by the end of March, not all states responded in the same way. In this article, I summarize the changes to state UI rules in response to the crisis and explore factors that have contributed to the variation in states' responses.

JEL classification: H72, J65

Key words: COVID-19, Unemployment insurance, Fiscal policy

\section{About the Author:}

Zoe Xie is a research economist and assistant adviser on the macroeconomics and monetary policy team in the Research Department at the Federal Reserve Bank of Atlanta. Her major field of research is macroeconomics with particular interests in labor markets and public finance. Prior to joining the Bank in 2016, she worked as a research analyst at the Federal Reserve Bank of Minneapolis and as an instructor at the University of Minnesota while pursuing graduate degrees. Xie received her doctoral and master's degrees from the University of Minnesota and her bachelor of arts degree in economics and mathematics from Williams College in Massachusetts.

Acknowledgments: The author would like to thank Lei Fang, Karen Kopecky, Ed Nosal, Melinda Pitts, and Tao Zha for helpful comments. The views expressed here are the author's and not necessarily those of the Federal Reserve Bank of Atlanta or the Federal Reserve System. Any remaining errors are the author's responsibility.

Comments to the author are welcome at zoe.xie@ atl.frb.org. 
The COVID-19 pandemic led to an unprecedented expansion in unemployment insurance (UI) eligibility across states. States are often able to respond faster than the federal government to economic emergencies, and the COVID-19 crisis was no exception. By the end of March, more than forty states had passed modified UI eligibility rules to help affected workers. In contrast, the federal government's Coronavirus Aid, Relief, and Economic Security (CARES) Act, passed on March 27, 2020, did not become effective until early April. ${ }^{1}$

Not all states have responded to the crisis in the same way. More than half of states extended eligibility to include workers unable to work as a result of quarantine or illness related to COVID-19. About one third of states extended coverage to workers caring for family with illness related to COVID-19 or children at home because of school closure. A few states extended coverage to selfemployed workers, who are usually not eligible to apply. While many states substantially increased eligibility coverage, others did not adjust their UI programs at all. What accounts for the variation in states' responses?

In this article, I summarize the key changes in states' UI eligibility rules in response to COVID-19 and explore factors that potentially contributed to the different responses by states. States with larger shares of service-sector employment were more likely to extend UI eligibility coverage. States with more confirmed COVID-19 cases were slightly more likely to extend coverage to workers caring for sick family members or at-home children. The solvency of a state's UI fund did not limit the expansion of UI coverage. In fact, states with worse-funded UI programs were more likely to expand coverage during this crisis.

Adapting social policies such as unemployment insurance swiftly to an economic or social crisis can provide important relief. Specific to the current situation, extending UI coverage to previously ineligible workers provides income to the many American workers who have little backup funds and are unable to work. ${ }^{2}$ Increasing the UI eligibility coverage can also help keep sick workers home, which is important for slowing down the virus's spread. ${ }^{3}$

\section{Key changes in states' UI rules}

I first summarize state UI policy changes in response to the spread of COVID-19 in March 2020. These changes are usually announced through an emergency executive order issued by the governor's office. The appendix provides details on the changes for each state.

\footnotetext{
${ }^{1}$ In the United States, the unemployment insurance program is a federal-state partnership based upon federal law but administered by state employees under state law," according to the U.S. Department of Labor. During normal times, states decide benefit eligibility criteria, the size of the benefit, and requirements for continued benefit collection. During recessions or emergencies such as the current situation, the federal government may pass supplementary UI rules that apply to all states, and the federal government funds these supplements.

${ }^{2}$ Kaplan, Violante, and Weidner (2014) find that from 25 percent to 40 percent of U.S. households live from paycheck to paycheck.

${ }^{3}$ This logic is similar to Chetty (2008)'s finding that the liquidity effect of UI can lengthen workers' unemployment duration. Under normal circumstances the $\mathrm{UI}$ system is designed to minimize such work disincentive. But in the current crisis, the opposite may be true. At least in the short run, slowing the virus's spread by keeping sick workers away from the workplace is arguably a public health and economic priority. Extended UI eligibility can be important in keeping mildly sick and potentially contagious workers home, especially in industries where paid sick days are traditionally not available (for example, in the meat processing industry), as a March 20 article in Bloomberg News noted (Shanker and Mulvany 2020). Given the logistics involved in implementing any new policy, using the UI system to provide this short-term liquidity to workers may also be more effective and less time-consuming than establishing a new system specifically designed to keep sick workers home.
} 
- Worker search requirement. Undertaking weekly job search activities is typically part of the requirement for a worker to continue collecting benefits. However, to promote social distancing and reduce the spread of the novel coronavirus, more than forty states have temporarily waived or relaxed the job search requirement. Some-including Maine, Maryland, Nevada, North Dakota, Pennsylvania, Texas, Washington, West Virginia, and Wisconsin-waived it for all unemployed workers, and some states only waived it for claims related to COVID-19 (including Hawaii, lowa, Kansas, Louisiana, and North Carolina) or new claims approved after certain dates (such as Georgia and Virginia). A few (California, Minnesota, and Oregon) modified the search requirement to online search only.

- $\quad$ "Able and available" requirement. Being "able and available" for work is another important criterion for continued collection of UI benefits. Quarantine or illness related to COVID-19 could make workers unable to work, and caring for family with COVID-19 illness or at-home children would make workers unavailable for work. In response to the current unusual situation, some states have modified the concept of "able and available." Alabama modified the rules to include those who are quarantined, sick, or taking care of family. Delaware and North Dakota treated quarantined or sick workers as if they are on temporary leave (and hence eligible for unemployment benefits). Illinois relaxed the "able" standard by requiring workers to only demonstrate ability to do certain work from home (for example, transcribing or data entry). Kansas assumed affected workers are able and available for work unless they refused suitable work due to illness. Massachusetts made similar concessions and without the requirement to accept suitable jobs unless the situations that prevent workers from working have been resolved. Arizona, Michigan, and New Hampshire extended coverage to workers who are quarantined, sick, caring for sick family, or taking care of at-home children. Oregon considered workers who are sick at home or quarantined and asymptomatic as able to work. West Virginia waived the "able and available" requirement.

- $\quad$ Self-employed workers. A few states-such as Kentucky, New Hampshire, and New Yorkextended coverage to self-employed workers, contract workers, and small business owners, who under usual circumstances are not covered by state UI unless they have worked for an employer in the past 18 months.

- Interpretation of "at fault" and "good cause." Workers who miss work due to fear of the virus but are not under quarantines recommended by a physician, the employer, or the government would be considered quitting without a good cause. While the majority of the states still do not provide coverage to these workers, some states extended coverage to such workers who are expected to return to their original work. Florida and Kentucky considered a worker leaving work due to reasonable risk of exposure to COVID-19 not the worker's fault. States such as Alabama, Indiana, and Wyoming, on the other hand, explicitly treated asymptomatic workers missing work due to self-quarantine as "at fault" or not good cause.

- $\quad$ Additionally, all but eight states usually require a one-week waiting period after the unemployed worker is eligible but before benefits start paying. However, in response to the virus outbreak and in an effort to get checks to unemployed workers fast, more than half of states have temporarily waived the waiting period. Workers on temporary or permanent layoffs due to employer 
downsizing or closing are eligible under the usual UI rules, once they meet the state's requirements on work history. All states with partial benefit also cover workers whose hours are reduced due to the virus outbreak.

\section{Factors that may affect UI rule modifications}

\subsection{Setup and data}

States have modified their UI rules in very different ways. While a majority waived the job search and waiting period requirements, only a few extended UI coverage to self-employed workers. Among the changes that states implemented, there are large cross-state variations in the expansion of eligibility coverage to workers in four scenarios:

- workers under quarantine recommended/requested/ordered by a physician, the employer, or the government;

- workers with a confirmed, symptomatic case of COVID-19;

- workers leaving to care for a family member with COVID-19 illness;

- workers leaving to care for children as a result of school closure.

I look at the state-level variations in these policy changes. A state covers the scenario (dependent variable $=1$ ) if official documentation (such as information related to COVID-19 from a state unemployment insurance office or a governor's executive order) says so. The state does not cover the scenario (dependent variable $=0$ ) if the official documentation does not mention the specific scenario, the rule says eligibility is determined case by case, or it specifies that the scenario is not covered because the worker does not satisfy the "able and available" requirement. A few states use other insurance programs (such as disability, caregiving, or family leave) to cover a scenario, which I exclude in the analysis for that scenario.

I focus on three factors that may potentially affect a state's decision to extend UI eligibility.

1. Share of private employment in the service sector

- Workers in the service sector are often the most at risk for exposure to the coronavirus, as their work requires close contact. The service sector is also the hardest hit by the quarantines and business slowdowns. As such, states with more workers in the service sector may have a stronger incentive to expand UI eligibility to reach more affected workers.

- Service sector employment and total private employment data are from the Quarterly Census of Employment and Wages produced by the U.S. Bureau of Labor Statistics (BLS). I use the most recent data, from the third quarter of 2019 , to calculate the percentage share.

\section{Number of confirmed COVID-19 cases}

- Similarly, states with more confirmed cases and hence more potentially affected workerseither through self-quarantine, sickness, or having to take care of family members-may have a stronger incentive to expand eligibility. 
- I take the total number of cases confirmed by March 28, 2020, from the Centers for Disease Control and Prevention (CDC). (I exclude the state of New York for the analysis using this variable as the sheer number of cases in New York makes it an outlier.)

\section{UI fund solvency}

- Since it may be costly to expand UI coverage, states with poorly funded UI programs may be more reluctant to do so.

- I use the Average High Cost Multiple index, published by the U.S. Department of Labor, for the year 2020. This index captures the state's ability to fully fund future unemployment benefits. It is calculated using the state trust balance at the end of 2019, divided by average of the three highest years of benefit payments. An index of 1 means the state's UI fund is expected to exactly cover its highest future UI obligations. A higher index indicates the fund is better funded.

\subsection{Results}

Bar Chart. For each factor, I group states according to whether it is above or below the median. I then compute the share of states in the group with extended coverage to each type of workers (quarantined, sick, caring for family, or caring for children). These are shown in figure 1.

\section{Figure 1}

(a) Service Sector Share of Employment

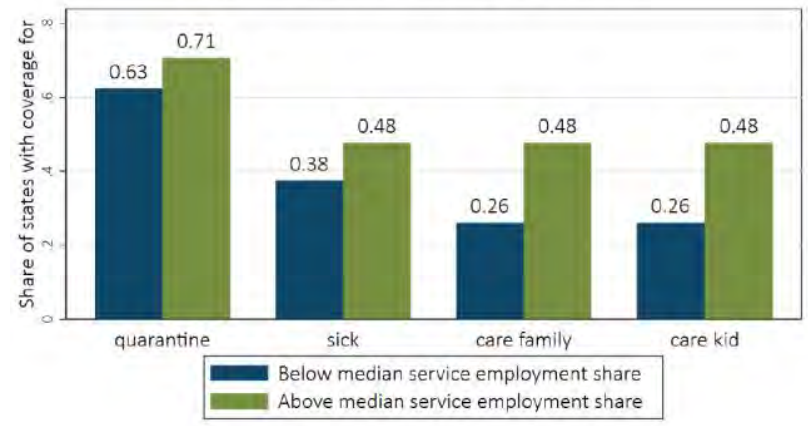

(b) Confirmed COVID-19 Cases

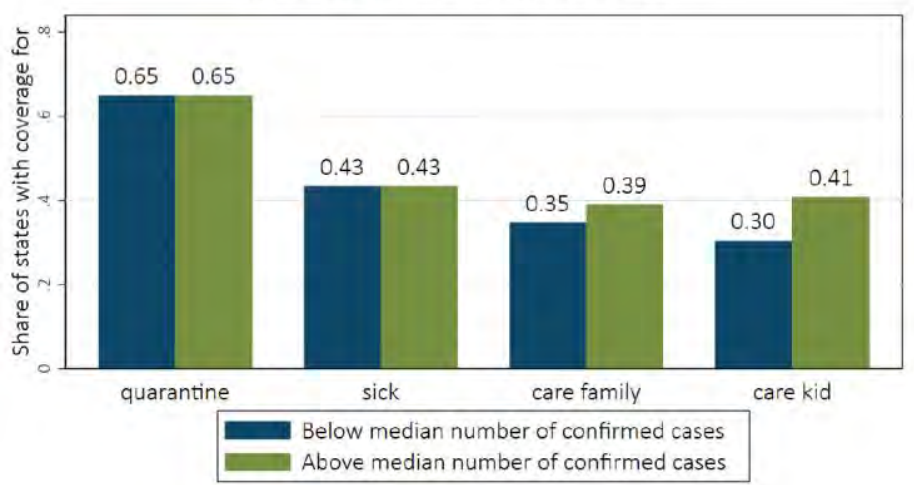


(c) UI Fund Solvency Index - Average High Cost Multiples

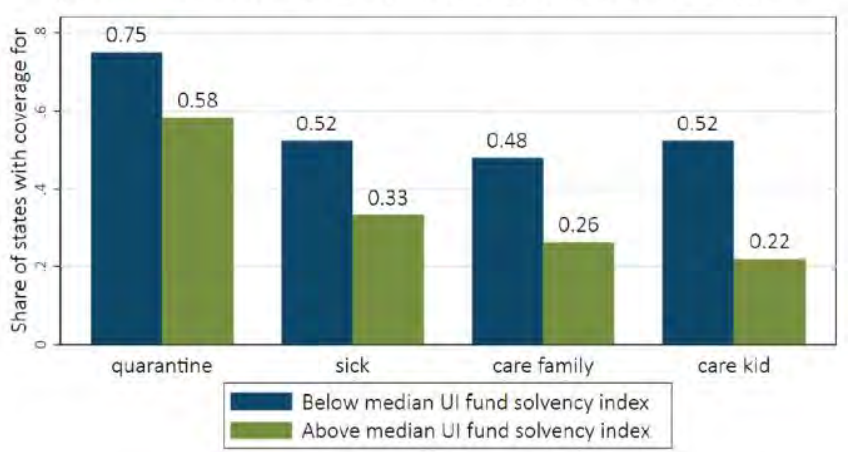

Notes: The graph shows the share of states with below- or above-median (a) service sector share of employment, (b) confirmed COVID-19 cases, and (c) UI fund solvency indexes that extend coverage to workers who are not usually eligible for UI benefits. The graph grouped the worker's reason for leaving work: under quarantine as recommended/requested/ordered by a physician, the employer, or the government; contracted COVID-19; caring for family with COVID-19 illness; or caring for children due to school closure.

Source: BLS Quarterly Census of Employment and Wages, CDC, U.S. Department of Labor's State Unemployment Insurance Trust Fund Solvency Report 2020, and state unemployment insurance agencies.

1. Service sector share of private employment. Panel (a) shows that states with a service employment share below the median are less likely to provide extended coverage. The pattern is especially stark for the coverage of workers caring for sick family or at-home children. Of the states with a service employment share below the median, 26 percent offered coverage for those workers, compared to 48 percent among states with above-median service employment share. For example, the state with the lowest service employment share, Wyoming, covered none of the scenarios, while Washington, DC-with the highest service employment share-covered three of the four scenarios.

2. Number of confirmed COVID-19 cases. Panel (b) shows that states with greater numbers of confirmed COVID-19 cases are more likely to extend coverage to workers caring for a sick family member or an at-home child. For example, Massachusetts, Michigan, and Illinois, which covered all four scenarios, are among the top 10 in terms of confirmed cases, while Wyoming, Nebraska, and Hawaii, which covered none of the scenarios, are among the 10 states with the least confirmed cases. ${ }^{4}$

3. UI fund solvency. Panel (c) shows that, contrary to what one would expect, states with worsefunded UI programs are actually more likely to extend coverage. For example, Illinois (index 0.42 ) and Massachusetts (0.57) covered all four scenarios, whereas Nebraska (1.75) and Nevada (1.52) covered none of the scenarios. The relationship is most striking for the coverage of workers caring for sick family or at-home children. Among states with belowmedian UI fund solvency index (about 1.1), 48 percent provide coverage to workers caring for sick family and 52 percent provide coverage to those caring for at-home children, compared to 26 percent and 22 percent, respectively, among states with above-median UI fund solvency index. There are potentially two reasons that the solvency of a state's UI fund did not limit states' expansion of UI coverage. First, states likely expected the federal government to soon

\footnotetext{
${ }^{4}$ The total number of COVID-19 related deaths, on the other hand, does not show a positive correlation with extended coverage.
} 
step in and take over paying for the extended coverage. Second, states with more generous UI benefits during normal times are more likely to have poorly funded UI programs and may also be more willing to extend UI eligibility during a crisis. Indeed, I find that a state's maximum potential UI benefit amount in 2019 positively correlates with extended coverage to workers in all four scenarios. ${ }^{5}$

Logit Regression. As another way to illustrate the results, I use a single-variate logit regression setup. The table summarizes the coefficients of these logit regressions.

Coefficient from Single-Variate Logit Regressions of State Expansion of UI Coverage

\begin{tabular}{lcccc}
\hline \hline Factors & Quarantine & COVID-19 illness & Care for sick family & Care for at-home kids \\
\hline Service share of employment (\%) & 0.042 & 0.055 & 0.12 & $0.16^{* *}$ \\
Confirmed COVID-19 cases & 0.000058 & 0.00023 & 0.00050 & 0.00049 \\
UI fund solvency index & -0.85 & $-1.08^{*}$ & -0.78 & $-1.71^{* *}$ \\
\hline
\end{tabular}

Notes: Results are from single-variate logit regressions, meaning that each cell is from one separate logit regression. ${ }^{* *}$ indicates that logit regression results are significant at 5 percent, and * indicates that logit regression results are significant at 10 percent. Quarantine includes quarantines recommended/requested/ordered by a physician, the employer, or the government.

Sources: Service sector employment and total private employment are from the BLS Quarterly Census of Employment and Wages for the third quarter of 2019. The number of confirmed COVID-19 cases come from the CDC as of March 28, 2020. The Average High Cost Multiple Index is from data provided by the U.S. Department of Labor as of January 1, 2020.

1. Service sector share of private employment. Service sector employment share positively correlates with all four eligibility expansions. Among these, the correlation with the coverage of workers caring for at-home children is significant at the 5 percent level. A 1 percentage point increase in the service share of employment increases the log odds of a state offering coverage to these workers by 0.16 .

2. Number of confirmed COVID-19 cases. The number of confirmed COVID-19 cases is also positively correlated with all four coverage extensions, although none is statistically significant.

3. UI fund solvency. Consistent with findings shown in figure 1, states with worse-funded UI programs were more likely to extend coverage. The relationship is statistically significant for coverage of the sick and those caring for children. A 1 point increase in the UI fund solvency index, which ranges from 0.21 to 2.53 , lowers the log odds of a state offering coverage to those workers by 1.08 and 1.71 , respectively.

In addition, I consider the governor's party affiliation and the share of older population. States with a Democratic governor were more likely to extend eligibility coverage to workers caring for sick family or at-home children. A larger share of elderly population positively correlates with extended

\footnotetext{
${ }^{5}$ Maximum potential UI benefit data are from BLS report Comparison of State Unemployment Laws 2019 and is the product of the maximum weekly benefit amount and the maximum benefit duration.
} 
coverage to workers caring for sick family but negatively correlates with coverage for workers caring for at-home children. ${ }^{6}$

\section{Conclusion}

Recent evidence has shown that state governments can usually react faster than the federal government in a crisis, which is why state-level changes to $\mathrm{UI}$ rules in an emergency situation such as COVID-19 can be critical for households. This article summarizes the key changes in state UI rules during March 2020. There is a large variation across states in whether and how they responded. The article further investigates factors that contributed to the variations in states' responses. The service sector employment share contributes positively to state extending coverage, especially to workers caring for children at home due to school closure. The number of confirmed COVID-19 cases positively correlates with more actions by the state, although the relationship is not statistically significant. The solvency of a state's UI fund does not seem to limit its responses. One caveat to the findings here is how fast states can process unemployment benefit checks and get the money to workers. Anecdotal evidence suggests significant delays and, as a result, the workers who are covered as a part of states' extended eligibility coverage may not be able to get the unemployment check in a timely manner. Nevertheless, states that extended UI coverage early on may be better positioned (for example, by modifying the existing online system or mobilizing the necessary manpower to handle additional applications) to process unemployment checks to newly eligible workers even after the federal CARES Act comes into effect. The actual impact of state's extended UI coverage during this crisis will be an interesting avenue for future research.

\section{References}

Chetty, Raj. 2008. Moral Hazard versus Liquidity and Optimal Unemployment Insurance. Journal of Political Economy vol. 116 no. 2, 173-234.

Kaplan, Greg, Giovanni L. Violante, and Justin Weidner. 2014. The Wealthy Hand-to-Mouth. Brookings Papers on Economic Activity, Spring 2014, 77-144.

Shanker, Deena, and Lydia Mulvany. "Threat of Sick Workers at U.S. Meat Plants Forces Policy Changes. Bloomberg News online, March 20, 2020. <https://www.bloomberg.com/news/articles/2020-03-20/threat-of-sick-workers-at-u-smeat-plants-forces-policy-changes> (accessed March 20, 2020)

\footnotetext{
${ }^{6}$ I use the states' population share of residents 65 and older, data that are available from the U.S. Census Bureau. A more accurate measure for the vulnerable group would be the share of population over 60, according to CDC guidelines.
} 
FEDERAL RESERVE BANK OF ATLANTA'S POLICY HUB • No. 02-2020

Appendix: Changes in State Unemployment Insurance Rules in Response to COVID-19

\begin{tabular}{|c|c|c|c|c|c|c|c|c|}
\hline \multirow[b]{2}{*}{ States } & \multirow[b]{2}{*}{ Waiting period } & \multirow[b]{2}{*}{ Weekly job search } & \multicolumn{5}{|c|}{ Rules modified to cover } & \multirow[b]{2}{*}{ Other new coverage } \\
\hline & & & $\begin{array}{l}\text { Recommended } \\
\text { quarantine }\end{array}$ & $\begin{array}{l}\text { Self-imposed } \\
\text { quarantine }\end{array}$ & COVID-19 illness & $\begin{array}{l}\text { Caring for sick } \\
\text { family }\end{array}$ & $\begin{array}{l}\text { Caring for at- } \\
\text { home kids }\end{array}$ & \\
\hline Alabama $^{1}$ & waived for impacted & waived for impacted & covered & not covered & covered & covered & - & \\
\hline Alaska & - & waived & covered & case by case & case by case & - & case by case & \\
\hline Arizona & waived & wa.ived & covered & case by case & covered & covered & covered & \\
\hline Arkansas & waived & waived for new claims & - & - & - & - & - & \\
\hline California & waived & waived or relaxed & covered & case by case & covered by DI/UI & covered by FL/UI & covered & \\
\hline Colorado & - & - & not covered & not covered & not covered & not covered & not covered & \\
\hline Connecticut & no waiting period & waived & case by case & case by case & case by case & not covered & case by case & \\
\hline Delaware $^{2}$ & waived & waived & covered & case by case & covered & covered & covered & \\
\hline D.C. & - & - & covered & - & covered & case by case & covered & \\
\hline Florida & - & waived & not covered & covered & not covered & covered & not covered & \\
\hline Georgia & no waiting period & waived for new claims & - & case by case & covered & covered & covered & \\
\hline Hawaii & waived for impacted & waived for impacted & covered by TDI & - & covered by TDI/WC & covered by FL & covered by FL & \\
\hline $\begin{array}{l}\text { Idaho } \\
\text { Illinois }{ }^{3}\end{array}$ & waived & waived for temp layoff & $\begin{array}{l}\text { covered } \\
\text { covered }\end{array}$ & case by case & not covered & not covered & not covered & \\
\hline $\begin{array}{l}\text { Illinois }{ }^{3} \\
\text { Indiana }\end{array}$ & & waived & covered & $\begin{array}{l}\text { case by case } \\
\text { not covered }\end{array}$ & covered & covered & covered & \\
\hline $\begin{array}{l}\text { Indiana } \\
\text { Iowa }\end{array}$ & $\begin{array}{l}\text { not waived } \\
\text { no waiting period }\end{array}$ & waived for impacted & $\begin{array}{l}\text { covered } \\
\text { case by case }\end{array}$ & $\begin{array}{l}\text { not covered } \\
\text { case by case }\end{array}$ & $\begin{array}{l}\text { covered } \\
\text { covered }\end{array}$ & $\begin{array}{l}\text { case by case } \\
\text { con }\end{array}$ & covered & \\
\hline Kansas $^{4}$ & waived for impacted & waived for impacted & covered & - & covered & covered & covered & \\
\hline Kentucky & waived & waived for temp layoff & covered & covered & - & covered & covered & $\begin{array}{l}\text { Coverage expanded } \\
\text { to include self- } \\
\text { employed }\end{array}$ \\
\hline Louisiana & waived for impacted & waived for impacted & - & - & - & - & - & \\
\hline Maine & waived & waived & case by case & - & not covered & case by case & case by case & \\
\hline Maryland & no waiting period & waived & covered & case by case & covered & covered & & \\
\hline Massachusetts ${ }^{5}$ & waived & - & covered & case by case & covered & covered & & \\
\hline Michigan & no waiting period & waived & covered & case by case & covered & covered & covered & $\begin{array}{l}\text { Benefits extended } \\
\text { from } 20 \text { to } 26 \text { weeks }\end{array}$ \\
\hline Minnesota & waived & relaxed & covered & case by case & covered & covered & covered & \\
\hline Mississippi & waived & waived for new claims & covered & - & $\begin{array}{l}\text { currently not cov- } \\
\text { ered }\end{array}$ & $\begin{array}{l}\text { currently not cov- } \\
\text { ered }\end{array}$ & $\begin{array}{l}\text { currently not } \\
\text { covered }\end{array}$ & \\
\hline Missouri & waived for impacted & waived for temp layoff & covered & case by case & case by case & - & not covered & \\
\hline Montana & & waived for temp layoff & covered & not covered & not covered & covered & not covered & \\
\hline Nebraska & - & waived for new claims & - & - & not covered & - & - & \\
\hline Nevada & no waiting period & waived & - & - & - & - & - & \\
\hline New Hampshire & waived & & covered & - & covered & covered & covered & $\begin{array}{l}\text { Coverage expanded } \\
\text { to self-employed and } \\
\text { small business own- } \\
\text { ers }\end{array}$ \\
\hline $\begin{array}{l}\text { New Jersey } \\
\text { New Mexico }\end{array}$ & $\begin{array}{l}\text { no waiting period } \\
\text { not waived }\end{array}$ & $\overline{\text { waived }}$ & $\begin{array}{l}\text { covered by WC } \\
\text { covered }\end{array}$ & $\begin{array}{l}\text { covered by TDI } \\
\text { not covered }\end{array}$ & covered by TDI/WC & $\begin{array}{l}\text { covered by FL } \\
\text { covered }\end{array}$ & $\begin{array}{l}\text { use sick leave } \\
\text { not covered }\end{array}$ & \\
\hline New York & waived for impacted & waived & $\begin{array}{l}\text { covered by sick } \\
\text { leave }\end{array}$ & - & covered by WC/TDI & $\begin{array}{l}\text { covered by sick } \\
\text { leave }\end{array}$ & $\begin{array}{l}\text { covered by } \\
\text { emergency FML }\end{array}$ & $\begin{array}{l}\text { Coverage expanded } \\
\text { to independent con- } \\
\text { tractor with an em- } \\
\text { ployer, e.g. gig- } \\
\text { workers }\end{array}$ \\
\hline
\end{tabular}

continued on the next page... 
FEDERAL RESERVE BANK OF ATLANTA'S POLICY HUB・ No. 02-2020

Changes in State Unemployment Insurance Rules in Response to COVID-19, continued

\begin{tabular}{|c|c|c|c|c|c|c|c|}
\hline \multirow[b]{2}{*}{ States } & \multirow[b]{2}{*}{ Waiting period } & \multirow[b]{2}{*}{ Weekly job search } & \multicolumn{5}{|c|}{ Rules modified to cover } \\
\hline & & & $\begin{array}{l}\text { Recommended } \\
\text { quarantine }\end{array}$ & $\begin{array}{l}\text { Self-imposed } \\
\text { quarantine }\end{array}$ & COVID-19 illness & $\begin{array}{l}\text { Caring for sick } \\
\text { family }\end{array}$ & $\begin{array}{l}\text { Caring for at- } \\
\text { home kids }\end{array}$ \\
\hline North Carolina & waived for impacted & waived for impacted & covered & - & case by case & - & - \\
\hline North Dakota & - & waived & covered & - & covered & - & - \\
\hline Ohio $^{6}$ & waived & waived & covered & case by case & case by case & case by case & - \\
\hline Oklahoma & waives & waived & - & - & - & - & - \\
\hline Oregon $^{7}$ & - & waived or relaxes & covered & case by case & covered & covered & covered \\
\hline Pennsylvania & waived & waived & covered & case by case & - & - & covered by FML \\
\hline Rhode Island $^{8}$ & waived for impacted & - & covered by TDI/TCI/UI & - & covered by TDI/TCI & covered by TDI/TCI & covered \\
\hline South Carolina & - & - & not covered & not covered & not covered & not covered & not covered \\
\hline South Dakota & - & - & covered & not covered & covered & not covered & not covered \\
\hline Tennessee & - & waived for temp layoff & covered & not covered & - & not covered & - \\
\hline Texas & waived for impacted & waived & covered & not covered & covered & case by case & covered \\
\hline Utah & not waived & case by case & case by case & not covered & not covered & - & - \\
\hline Vermont & - & waived for temp layoff & covered & - & covered if recovered & covered by FML & covered by FML \\
\hline Virginia & waived & waived for new claims & - & - & - & - & - \\
\hline Washington & waived & waived & covered & - & covered & case by case & case by case \\
\hline West Virginia $^{9}$ & waived & waived & covered & - & covered & - & - \\
\hline Wisconsin & waived & waived & covered for temp leave & not covered & not covered & not covered & not covered \\
\hline Wyoming & no waiting period & - & not covered & not covered & not covered & - & - \\
\hline
\end{tabular}

Notes: Recommended quarantine includes quarantines recommended/requested/ordered by a physician, the employer, or the government. Self-imposed quarantine includes those that are not among the recommended quarantines, such as refusal to go to work due to risk of the virus and worker is not part of a high-risk (older than 60 or with underlying conditions) group. (T)DI indicates (temporary) disability insurance. ( $\mathrm{T}$ ) Cl indicates (temporary) caregiver insurance. (P)FL indicates (paid) family leave. F(M)L indicates family (medical) leave. UI indicates unemployment insurance. WC indicates worker compensation. All states cover under usual rules not-at-fault temporary layoffs and firing due to employer downsizing or closing. States with partial unemployment insurance continue to cover reduced hours. I use "- " to indicate when no special provision for a scenario is mentioned in the state's official document and treat these as "case by case" in the analysis.

Notes on states: 1. Alabama treats affected workers as able to and available for work. 2. Delaware treats medically quarantined, sick, and caring for sick family or at-home kids as temporary layoffs and hence eligible for benefits. 3. Illinois requires workers to demonstrate ability to do certain work from home (for example, transcribing or data entry) to be considered able to work. 4. Kansas treats workers who miss work due to COVID-19 as able to work unless they refuse suitable offer due to illness. 5. Massachusetts considers affected workers as temporary leaves if they expect to return to work, or they are considered medical leave if not. There is no requirement to accept suitable work in the meantime. 6 . Ohio covers illness related to COVID-19 and caring for family or children only if the leaves are requested by the employer. 7. Oregon considers people sick at home and asymptomatic quarantines as able to work; workers who are hospitalized are considered on a case-by-case basis. 8. Rhode Island covers sick workers with temporary disability or temporary caregiver insurance if unable to work, and unemployment insurance for quarantined but asymptomatic workers. The state may extend eligibility coverage to independent contractors and self-employed. 9. West Virginia waived able-and-available to work requirement for quarantined and sick.

Source: State unemployment insurance agencies and governors' executive orders as of March 28, 2020 